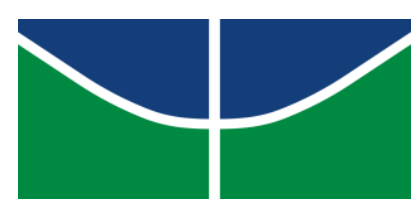

Universidade de Brasília Instituto de Artes

Departamento de Artes Visuais

Curso de Licenciatura em Artes Visuais

REJANE ALMEIDA DA CRUZ

\title{
A UTILIZAÇÃO DA IMAGEM NA APRENDIZAGEM DOS ALUNOS NA DISCIPLINA DE ARTES VISUAIS DO ENSINO FUNDAMENTAL
}




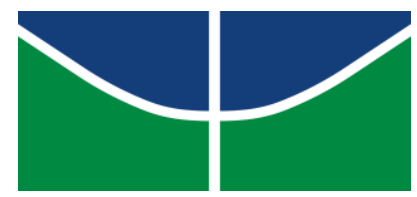

Universidade de Brasília Instituto de Artes

Departamento de Artes Visuais

Curso de Licenciatura em Artes Visuais

REJANE ALMEIDA DA CRUZ

\section{A UTILIZAÇÃO DA IMAGEM NA APRENDIZAGEM DOS ALUNOS NA DISCIPLINA DE ARTES VISUAIS NO ENSINO FUNDAMENTAL}

Trabalho de Conclusão de Curso em Artes Visuais, apresentado ao Departamento de Artes Visuais da Universidade de Brasília, como pré-requisito para obtenção do título de graduada em Licenciatura em Artes Visuais.

Orientador: Prof. Ms. Clerismar Aparecido Longo 


\section{A UTILIZAÇÃO DA IMAGEM NA APRENDIZAGEM DOS ALUNOS NA DISCIPLINA DE ARTES VISUAIS NO ENSINO FUNDAMENTAL}

Trabalho de Conclusão de Curso em Artes Visuais, apresentado ao Departamento de Artes Visuais da Universidade de Brasília, como pré-requisito para obtenção do título de graduada em Licenciatura em Artes Visuais.

Banca Examinadora

Prof. Ms. Clerismar Aparecido Longo (UAB/UnB)

Presidente

Prof. Ms. Gregório Soares Rodrigues de Oliveira (IdA/UnB)

Membro examinador

Profa. Ms. Carla Conceição Barreto (IdA/UnB)

Membra examinadora 
Dedico este trabalho a meus familiares, aos meus colegas, pela companhia nesta jornada de busca pela profissionalização, e a todos que de alguma forma contribuíram neste processo de formação. 


\section{AGRADECIMENTOS}

Agradeço primeiramente a Deus, por ter me abençoado nesta jornada, dando-me capacidade para seguir em frente e a buscar meus ideais, e pela oportunidade que ele me deu para eu prosseguir em meus estudos.

Aos meus familiares, pelo incentivo para continuar, vencendo os obstáculos que surgiram ao longo deste processo.

Aos professores, pela colaboração e incentivo, para que eu pudesse prosseguir nos estudos e assim finalizar esse curso com êxito.

Em especial, ao orientador Clerismar Aparecido Longo, pelas orientações concedidas, sugestões e subsídios para a elaboração deste Trabalho de Conclusão de Curso, que muito contribuiu com o meu desempenho no curso.

Aos meus colegas de turma, pelo companheirismo e amizades, principalmente às minhas amigas, Clediane Sena e Mirtes Rochas, pela dedicação ao longo desta caminhada. 


\section{RESUMO}

Sabemos que as imagens transmitem mensagens, conhecimentos, interpretações e podem contribuir com uma aprendizagem mais significativa aos alunos, em todas as disciplinas. O presente trabalho teve como tema: "A utilização da imagem na aprendizagem dos alunos na disciplina de Artes Visuais no Ensino Fundamental". Teve como objetivos: Discutir o uso da imagem no processo de ensinoaprendizagem da disciplina de Artes no ensino fundamental; Reconhecer a importância do estudo com imagens diversas e o que elas representam na aprendizagem dos alunos; Reconhecer as contribuições das imagens utilizadas de forma interdisciplinar na formação dos alunos na disciplina de Artes Visuais; Verificar se os professores utilizam as imagens em sua prática docente na disciplina de artes e em qual frequência; Discutir diferentes metodologias de análise de imagens para uma aprendizagem mais significativas dos alunos. A metodologia utilizada foi a da pesquisa bibliográfica, oportunizando uma maior compreensão do assunto abordado, além de entrevista aplicada aos professores para constatar se as imagens são utilizadas no processo ensino-aprendizagem dos alunos e quais seus benefícios. Através do mesmo, foi possível ter uma maior compreensão sobre as contribuições que o estudo com imagens proporciona na aprendizagem dos alunos na disciplina de Artes visuais na formação dos alunos no Ensino Fundamental.

Palavras-chave: Imagens, Artes Visuais, aprendizagem, Ensino-fundamental, alunos. 


\section{LISTA DE FIGURAS}

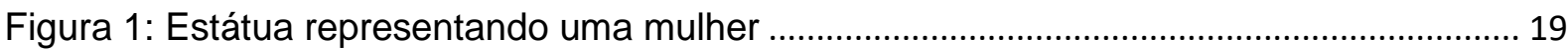

Figura 2: Eugène Delacroix - A Liberdade Guiando o Povo....................................................... 20

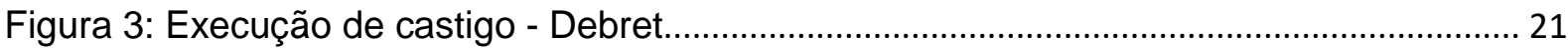

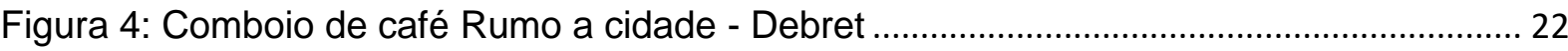

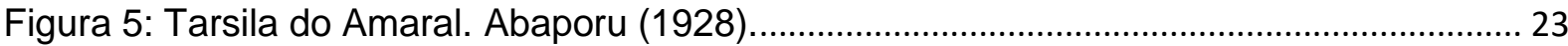


SUMÁRIO

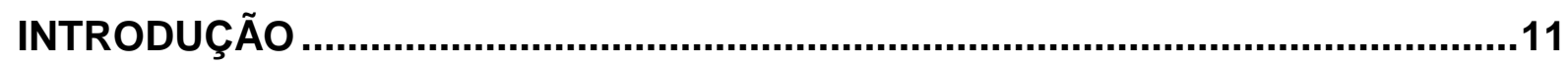

CAPÍTULO I - O ENSINO DE ARTES NA ESCOLA ...........................................13 1.1 ALGUMAS POSSIBILIDADES DE ESTUDO DE IMAGENS NAS AULAS DE ARTES 18

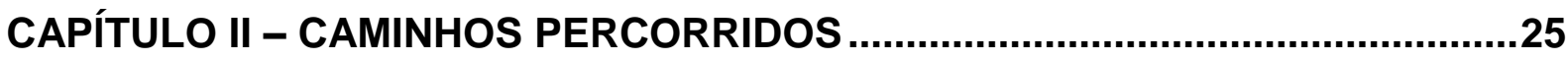

CAPÍTULO III - ANÁLISE E DISCUSSÃO DOS RESULTADOS ...........................27

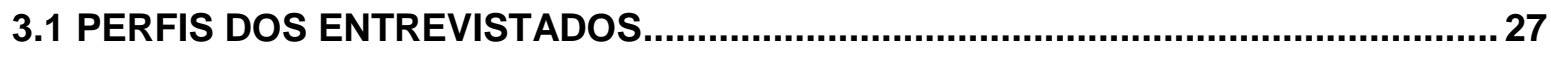

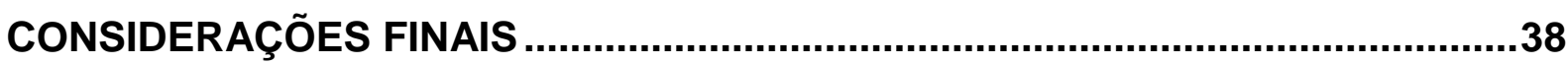

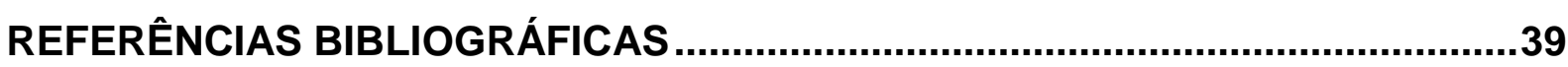

APENDICE - A 


\section{INTRODUÇÃO}

A presente monografia tem como tema: "A utilização da imagem na aprendizagem dos alunos na disciplina de Artes Visuais no Ensino Fundamental".

A pesquisa teve como objetivos: Discutir o uso da imagem no processo de ensino-aprendizagem da disciplina de Artes no ensino fundamental; Reconhecer a importância do estudo com imagens diversas e o que elas representam na aprendizagem dos alunos; Reconhecer as contribuições das imagens utilizadas de forma interdisciplinar na formação dos alunos na disciplina de Artes Visuais; Verificar se os professores utilizam as imagens em sua prática docente na disciplina de artes e em qual frequência; Discutir diferentes metodologias de análise de imagens para uma aprendizagem mais significativas aos alunos.

Sabemos que as imagens transmitem mensagens, conhecimentos, interpretações e podem contribuir com uma aprendizagem mais significativa aos alunos, em todas as disciplinas. Desta forma, a Arte pode ser uma área que pode estar interligada nas diversas áreas e juntas favorecer uma aprendizagem mais prazerosa e efetiva aos alunos.

Nesse sentido, este projeto teve como intuito discutir a relevância do uso e análise de imagens na disciplina de artes, tendo em vista uma aprendizagem mais significativa.

Destacam-se como problemas a serem investigados:

Que benefícios a imagem pode proporcionar na aprendizagem dos alunos na disciplina de Artes?

De que forma os professores trabalham com as imagens em suas práticas docentes para uma maior aprendizagem dos alunos na disciplina de Artes?

Para alcançar os objetivos elencados, a metodologia empregada foi a da pesquisa bibliográfica, o que oportunizou uma maior compreensão do assunto abordado, além de entrevista aplicada aos professores de algumas escolas da cidade de Cruzeiro do Sul/AC, para constatar se as imagens são utilizadas no processo ensino-aprendizagem dos alunos e quais seus benefícios.

Escolhi esse tema por considerar um tema de grande relevância na sociedade e na construção do processo de ensino-aprendizagem, tendo em vista que as Artes Visuais estão no nosso dia-a-dia, fazendo parte das nossas vidas. 
Dessa forma, dado o exposto, fez-se necessário analisar as contribuições que as imagens favorecem aos alunos, no ensino da disciplina de artes e suas contribuições a uma aprendizagem mais significativa, tendo em vista que através das imagens os alunos podem assimilar melhor um conteúdo, ilustrar um tema, contextualizar uma realidade, interpretar conteúdos diversos; além de proporcionar interação com os alunos, dinamismo, constituindo-se um recurso didático valioso na aprendizagem dos alunos nas diferentes Artes.

O tema é relevante na construção da aprendizagem dos alunos por discutir e analisar a presença das imagens nas aulas, as suas contribuições, metodologias que os professores podem estar utilizando na análise de imagens, dentre outros aspectos. E como o professor pode estar se apropriando das imagens em sua prática pedagógica, oportunizando através das imagens a presença das Artes visuais na aprendizagem dos alunos.

Através do mesmo, será possível ter uma maior compreensão sobre as contribuições que o estudo com imagens proporciona na aprendizagem dos alunos na disciplina de Artes na formação dos alunos no Ensino Fundamental. 


\title{
CAPÍTULO I - O ENSINO DE ARTES NA ESCOLA
}

As Artes visuais é uma modalidade de Artes bastante utilizada nas escolas e que traz contribuições relevantes na formação e aprendizagem dos alunos, se fazendo presente o apreciar, o fluir e o produzir.

\begin{abstract}
As artes visuais, além das formas tradicionais (pintura, escultura, desenho, gravura, arquitetura, artefato, desenho industrial), incluem outras modalidades que resultam dos avanços tecnológicos e transformações estéticas a partir da modernidade (fotografia, artes gráficas, cinema, televisão, vídeo, computação, performance). (BRASIL, 1998, p. 45).
\end{abstract}

Nesse sentido, observa-se que as artes visuais, em suas diferentes modalidades, se faz presentes na vida e aprendizagem dos alunos, constituindo a vivência estética e outras habilidades importantes aos estudantes.

\begin{abstract}
A educação de artes visuais requer entendimento sobre os conteúdos, materiais e técnicas com os quais se esteja trabalhando, assim como a compreensão destes em diversos momentos da história da arte, inclusive a arte contemporânea. Para tanto, a escola, especialmente nos cursos de Arte, deve colaborar para que os alunos passem por um conjunto amplo de experiências de aprender e criar, articulando percepção, imaginação, sensibilidade, conhecimento e produção artística pessoal e grupal. (BRASIL, 1998, p. 62).
\end{abstract}

Ainda desses aspectos acima mencionados, o Parâmetros Curriculares Nacionais (1998) destaca o papel da escola em proporcionar o universo jovem, trabalhando seus valores estéticos, escolhas artísticas e padrões visuais, ampliando o repertorio estético e favorecendo o posicionamento crítico dos alunos sobre as questões artísticas.

Segundo São Paulo (2006), o professor deverá proporcionar aos seus alunos a leitura das mais diversas obras de Arte e produtos artísticos, de todas as épocas, povos, países, culturas, gêneros, estilos, movimentos, técnicas, autores, artistas..., assim como as produções da própria classe envolvida.

Assim, nota-se que a imagem é complexa e traz contribuições diversas aos alunos, favorecendo ainda a competência para a produção da mesma.

Nos dias de hoje, a imagem visual tem uma inserção cada vez maior na vida das pessoas. Imagens nos são apresentadas e reapresentadas a todo 
o momento, num misto de criação e recriação. Nesse contexto, é importante desenvolver a competência do saber ver e analisar imagens, para que se possa, ao produzir uma imagem, fazer com que ela tenha significação tanto para o autor quanto para quem vai vê-la. Nesse sentido, é preciso conhecer a produção artística visual já existente, tanto a internacional quanto a nacional, regional e local, da comunidade, dando-lhe o devido valor. (CRUZ; 2009, p. 31).

Observa-se a importância do professor proporcionar aos alunos estudo e contato com imagens na disciplina de artes, ampliando o entendimento dos alunos e o significado da imagem, trazendo contribuições relevantes na aprendizagem dos alunos.

A utilização das imagens oportuniza aos alunos vivências significativas sobre diversos temas trabalhados em sala de aula, e a internet torna-se um recurso muito importante neste processo, como argumenta Brázia:

\begin{abstract}
A presença da imagem na sala de aula, num contexto de proximidade, manifesta-se nos manuais escolares, nas vivências dos alunos e nos materiais escolhidos pelo docente. Porém, no mundo atual, não podemos esquecer que muitas escolas já beneficiam do acesso à internet nas suas salas e algumas dispõem de quadros interativos. Nesse sentido, devemos pensar na imagem construída, nas imagens manipuladas, no recurso a filmes, a banda desenhada e outras formas de representação escolhidas pelo docente de acordo com os conteúdos adequados ao processo de leitura dos alunos, para se alcançar o desenvolvimento cognitivo desejado. (BRÁZIA, 2014, p. 6).
\end{abstract}

Assim, compreende-se que as imagens estão em nosso meio, seja num anúncio ou propaganda, em diversos espaços, dando visibilidade a acontecimentos históricos, experiências, representações, o que evidencia o poder das imagens e sua aplicação, podendo ser utilizada de forma interdisciplinar com os alunos.

Segundo Silva (2011), a visualidade também tem impacto sobre a aprendizagem. A capacidade das crianças de sentir uma imagem está se tornando cada dia mais presente e influente. Não se pode mais dizer que a escola é o único lugar que os alunos apreendem. Então, acreditamos que nós educadores devemos ensinar os conhecimentos artísticos culturais do passado associado aos dias atuais.

De acordo com Martins (1998), as orientações didáticas para o ensino da arte referem-se ao modo de realizar as atividades e às intervenções educativas junto dos estudantes nos domínios do conhecimento artístico e estético. 
A expressão leitura de imagens começou a circular na área de comunicação e artes no final da década de 1970 com a explosão dos sistemas audiovisuais. Essa tendência viu-se influenciada pelo formalismo, fundamentado na teoria da Gestalt, e pela semiótica. Na psicologia da forma, a imagem se constitui na percepção, já que toda experiência estética, seja de produção ou recepção, supõe um processo perceptivo. Essa abordagem entende a percepção como uma elaboração ativa, uma complexa experiência que transforma a informação recebida. (SARDELICH, 2006, p. 205).

Observa-se a importância da leitura de imagens na formação e aprendizagem dos alunos. E a disciplina de Artes é favorável à utilização constante de estudo com imagens, análise de imagens, releitura de imagens; produção de imagens, favorecendo uma maior aprendizagem em artes visuais.

A leitura e estudo de imagens fortalecem o desenvolvimento da cultura visual dos alunos e a interdisciplinaridade, como ressalta o autor abaixo:

$\mathrm{Na}$ abordagem da compreensão crítica, a cultura visual está entendida como um campo de estudo transdisciplinar multirreferencial que pode tomar seus referentes da arte, arquitetura, história, psicologia cultural, psicanálise lacaniana, construcionismo social, estudos culturais, antropologia, estudos de gênero e meios, sem fechar-se nessas ou somente sobre essas referências. Essa ampla e aberta proposta enfatiza que o campo de estudos não se organiza a partir de nomes de artefatos, fatos e ou sujeitos, mas sim em relação aos seus significados culturais, vinculando-se à noção de mediação de representações, valores e identidades. Para este autor, um estudo sistemático da cultura visual pode proporcionar uma compreensão crítica do seu papel e funções sociais, além das relações de poder às quais se vincula, indo além da apreciação ou do prazer que proporcionam. (SARDELICH, 2006, p. 214).

Segundo Arslan (2006), as leituras de objetos artísticos são outra competência importante na formação dos alunos, ao qual favorece a imagem produtiva do aprendiz, além de contribuir com a formação cultural, e sua conexão com a aprendizagem ao patrimônio cultural.

Ainda sobre a leitura e estudo de imagens, o autor ressalta:

O aluno, sujeito da aprendizagem, constrói seus saberes em arte ao estabelecer relações entre o percurso da criação de seus trabalhos e sua reflexão pessoal sobre as diferentes linguagens, tendo como referência a diversidade da arte produzida ao longo da história. (ARSLAN, 2006, P. 5).

Verifica-se a necessidade do aluno ter contato com análise de imagens, produção, criação, para que assim possa ampliar seu repertório cultural e desenvolver as diferentes linguagens artísticas em seu processo de criação e apreciação. 
O ensino da Artes acompanha os movimentos da Arte e da educação, refletindo o processo dinâmico que perpassa essas duas matrizes. Os paradigmas contemporâneos do ensino da Arte são fruto de conservações e mudanças, preservações e substituições, significações de questões estéticas e educacionais, como o papel da arte na escola e na escola, as relações entre conteúdos e método no ensino da arte e os modos de avaliação, os pressupostos do ensino e da aprendizagem, a visão da relação professor-aluno na articulação entre teoria e prática de ensino e aprendizagem em arte. (ARSLAN, 2006, p. 3).

O ensino da Artes evolui ao longo dos tempos, trazendo mudanças, novos significados e estéticas que afetam o espaço educacional. Destacando cada vez mais a importância do ensino da arte na escola, através de uma relação entre professor e aluno, vivenciada pela teoria e a prática, em que os alunos possam vivenciar arte, apreciar e produzir, a partir de sua compreensão de mundo.

\begin{abstract}
As leituras de objetos artísticos são outra competência que promove a imagem positiva do aprendiz, além de cumprirem o papel de formação cultural, conectam a aprendizagem ao patrimônio cultural. Na escola, o jovem compreende e se situa no mundo como agente transformador, ao atribuir e extrair significados das produções de críticos, historiadores, jornalistas, artistas e filósofos, com a mediação do professor. (ARSLAN, 2006, p. 9).
\end{abstract}

A partir da citação acima, observa-se que a visualidade fornecida pela leitura de imagens e objetos, traz contribuições relevantes na aprendizagem dos alunos, incluindo tanto o aspecto cultural, como significados e compreensões importantes que contribui com uma aprendizagem mais significativa através do ensino das artes.

Em relação ao PPP - Projeto Político Pedagógico de uma das escolas em que um dos professores foram entrevistados para esta pesquisa, foi possível verificar através do referido documento, que a escola tem os seguintes objetivos da disciplina de Artes:

- Realizar atividades que fortaleçam o espírito humano, melhore a qualidade de vida e promovam a criatividade, dignidade e a independência através das artes.

- Conhecer o mundo das artes e cultura através do desenvolvimento de atividades de músicas, danças, teatro, literatura, artes visuais, artesanatos, entres outros.

- Improvisar, compor e interpretar diferentes formas de dança.

- Desenvolver a percepção, fruição e análise crítica de movimentos corporais e coreografias na apreciação da dança. 
- Conhecer as dimensões históricas e culturais da dança e seus aspectos estéticos e saber distinguir, nos diversos contextos, as características da relação corpo-dança.

- Expressar-se nas modalidades da linguagem visual (desenho, pintura, gravura, tecelagem, cerâmica, escultura instalação), experimentando e pesquisando suas possibilidades.

- Desenvolver a autoconfiança com a sua própria produção plástica, relacionando com a dos colegas e de artistas da comunidade, valorizando e respeitando a diversidade artística das diversas etnias da cultura brasileira e de outras culturas.

- Conhecer e identificar as profissões e os profissionais de artes plásticas e comunicação visual da região, suas organizações de produção e de agremiação e sua forma de atuação na sociedade.

- Expressar-se e comunicar-se através da improvisação, composição e interpretação musicais.

- Fazer uso de grafias musicais convencionais e não convencionais.

- Apreciar, perceber, fruir e analisar obras musicais de diversas culturas e épocas.

- Perceber e identificar as relações entre uma obra musical e seu contexto cultural, histórico e geográfico de produção.

A partir desses objetivos, reconhecemos que o ensino de Artes na escola através das imagens, relacionam-se aos objetivos, pois visam a análise, interpretação, expressão, comunicação, apreciação e fruição, análise de obras, respeito a diversidade artística, criatividade utilizando diferentes possibilidades, dentre outras competências importantes que se faz presentes através do estudo e análise de imagens no Ensino Fundamental.

Dessa forma, destaca-se o papel da escola em proporcionar aos alunos um ensino de artes visuais, constituído através de estudo, análise, apreciação e produção de imagens, que favoreça o desenvolvimento artístico dos alunos e sua aprendizagem mais significativa.

Observa-se que a disciplina de Artes é de grande relevância na formação dos estudantes, favorecendo o seu desenvolvimento e aprendizagem de forma lúdica e criativa. 
Assim, nota-se a importância do ensino de artes visuais, também voltado à cultura artística local. Esse é um aspecto importante e que pode ser trabalhado nas aulas de Artes no Ensino Fundamental, permitindo aos alunos se apropriarem da artes visuais voltado a sua cultura local, levando os alunos a priorização dos artistas e produções locais, incluindo: dança da região, produções artísticas, artesanato, pinturas, dentre outras formas de manifestação dos aspectos visuais e da criatividade dos indivíduos que moram na região.

Estudar a arte local é relevante, pois além de valorizar e incentivar o desenvolvimento da arte local, torna-se uma opção de estudo e desenvolvimento das Artes visuais, favorecendo uma aprendizagem mais significativa dos alunos e contextualizada a realidade dos alunos.

\subsection{ALGUMAS POSSIBILIDADES DE ESTUDO DE IMAGENS NAS AULAS DE ARTES}

Sabemos que os professores de Artes podem se apropriar de diferentes tipos de imagens para estudo com seus alunos, por meio da apreciação, interpretação e releitura, como também para ilustrar um conteúdo; para contextualizar um assunto trabalhado; para facilitar a compreensão dos alunos; dentre outras finalidades importantes. Cada metodologia apresenta a sua relevância e contribuição à aprendizagem dos alunos, como também para despertar nos alunos o senso crítico e a sensibilidade estética, servindo de incentivo à formação de futuros artistas.

A seguir, alguns exemplos de trabalhos com imagens:

- Exemplo de análise de uma escultura 


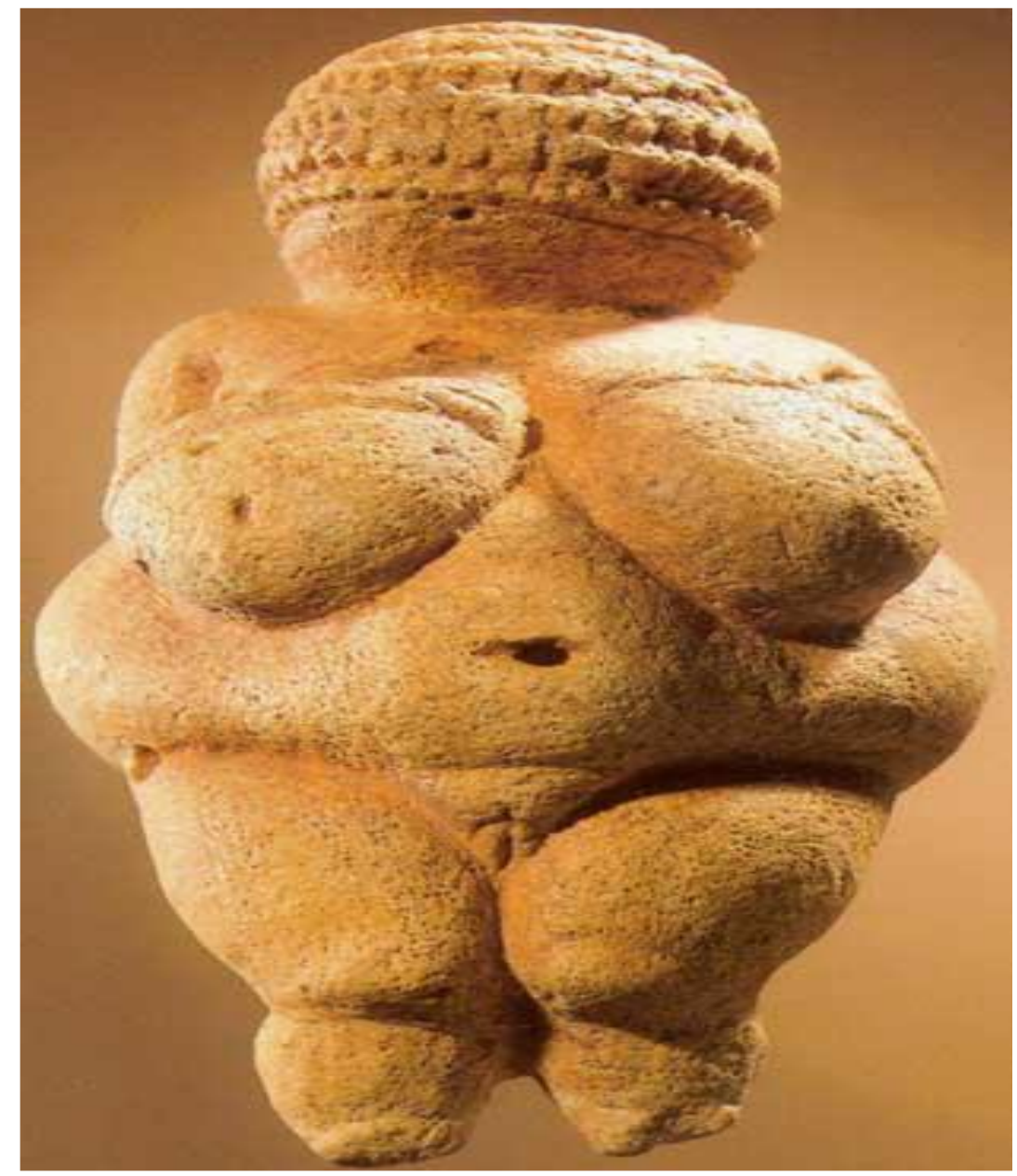

Figura 1: Estátua representando uma mulher

Fonte: http://www.kenneymencher.com/2016/07/why-is-venus-of-wilendorfso-important.html

O professor pode realizar questionamentos diversos para a análise da escultura, favorecendo aos alunos uma análise e compreensão da mesma. $O$ autor abaixo apresenta algumas sugestões para análise da imagem:

Após a identificação, por parte dos alunos, da origem da estátua, seu tamanho, constituição (material utilizado) e idade, pode-se indagá-los sobre sua estética: Quais suas características mais marcantes? Por que eles acham que a estátua possuía tais características? Qual seu objetivo ou finalidade? Qual o significado do corpo volumoso? É possível identificar simbolismos? Haveria um significado religioso? E hoje, qual a idealização que se faz da mulher e seu corpo? (LITIZ, 2009, p. 18).

Observa-se que são intervenções importantes que despertam nos alunos o senso crítico, a sensibilidade, as características da imagem, dentre outros aspectos relevantes e que favorecem a interpretação da mesma. 
- Contextualização de um conteúdo histórico (leitura e interpretação)

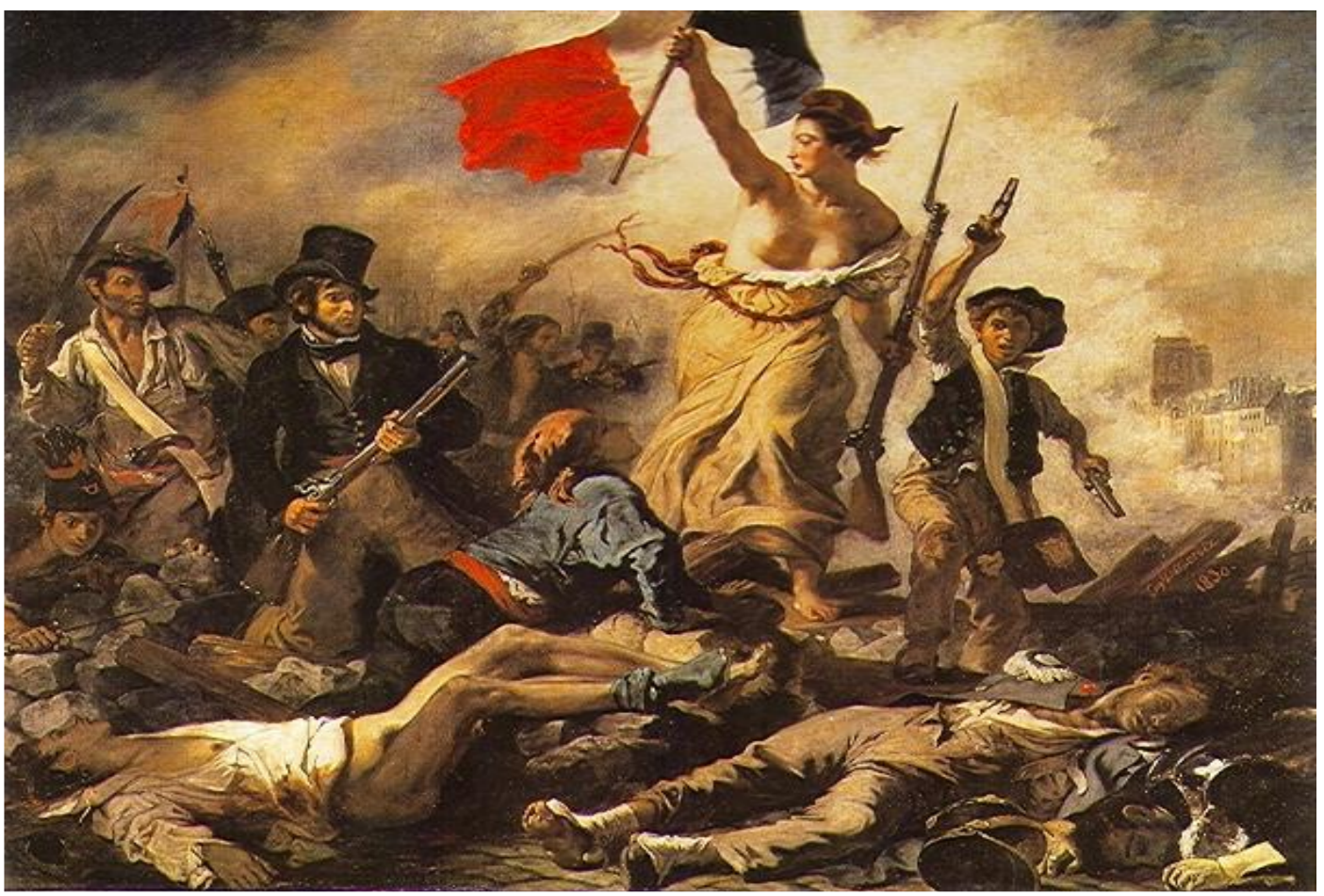

Figura 2: Eugène Delacroix - A Liberdade Guiando o Povo

Fonte: http://historiainformaticaifet.blogspot.com.br/2010/07/analise-do-quadro-liberdade-quiando$\underline{\text { o.html }}$

A partir da imagem acima, o professor pode trabalhar o contexto histórico para facilitar o entendimento do aluno sobre o conteúdo, além de oportunizar o estudo e apreciação da mesma.

A obra retrata a Liberdade guiando o povo, ao qual pode ser analisada com o seguinte roteiro:

- Identificação da obra, autor, período e técnica utilizada.

- Identificar o que está no centro e à frente da figura. Geralmente é o que o autor quis destacar. Qual é o tema da obra? O que o autor quis representar?

- Identificar todas as pessoas, construções e objetos que compõem a imagem.

- Verificar as ações que estão sendo retratadas. Qual é a principal? E as secundárias? Como se interligam?

Observar as expressões faciais e atitudes dos personagens. Cada movimento, cada detalhe pode revelar muito da obra e da intenção do autor. Observar o evento retratado como um todo, buscando a síntese do que está representado, procurando compreender a relação do autor e sua época, dentro daquele contexto histórico.

. É possível alguma relação com o contexto atual? (pode-se relacionar a pintura com a luta pelos valores democráticos e o liberalismo político, tão caros para as sociedades e até hoje idealizados). (LITIZ, 2009, p. 24 
São aspectos importantes que trazem aprendizados necessários a aprendizagem dos alunos e a sua formação cidadã, sendo necessário uma boa exploração da pintura através de diálogo e interação entre professor e aluno.

\begin{abstract}
Compreender uma imagem implica ver construtivamente a articulação de seus elementos, suas tonalidades, suas linhas e volumes. Enfim, apreciá-la, na sua pluralidade de sentidos, sejam imagens da Arte erudita, popular, internacional ou local; sejam produções dos alunos; o meio ambiente natural ou construído; imagens da televisão; informações visuais diversas presentes no cotidiano (BARBOSA, 2008, p. 81).
\end{abstract}

Observa-se que a autora atribui grande relevância à análise de obra, permitindo aos alunos apreciar também a diversidade de sentidos que a imagem proporciona e que faz parte do cotidiano dos alunos.

- Diálogo entre as disciplinas e conhecimento histórico e cultural

Outro exemplo relevante sobre a aprendizagem de conhecimentos históricos, refere-se às obras de Debret, que retratam um momento histórico de nosso Brasil referente à época da Escravidão. Como demonstra as imagens abaixo:

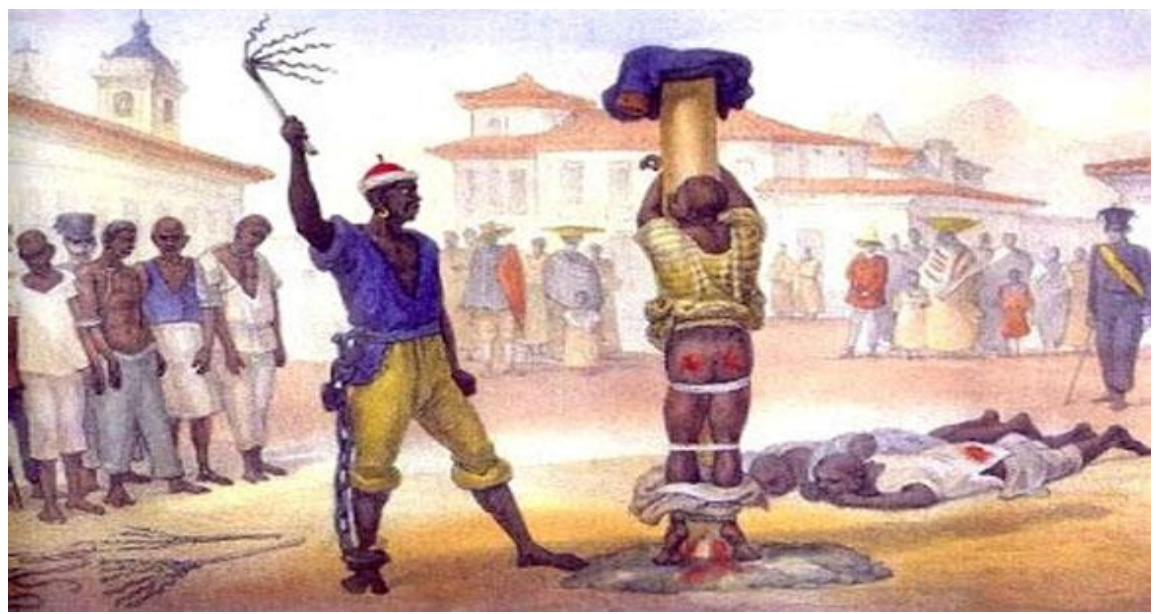

Figura 3: Execução de castigo - Debret

Fonte: https://pt.slideshare.net/marialuzinete/rugendas-e-debret-retratos-da-escravido-no-brasil 


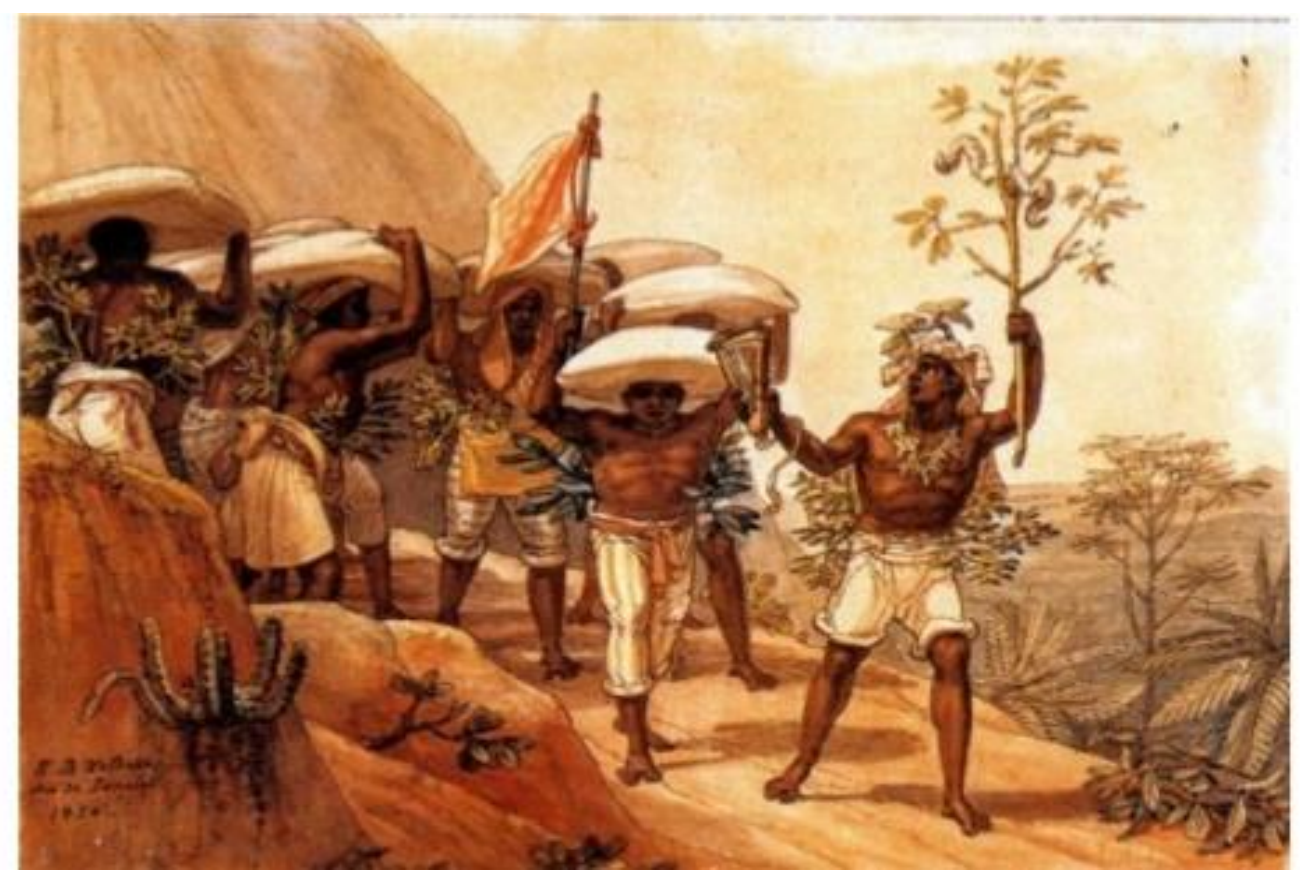

Figura 4: Comboio de café Rumo a cidade - Debret

Fonte: https://pt.slideshare.net/marialuzinete/rugendas-e-debret-retratos-da-escravido-no-brasil

Observa-se que são obras valiosas, produzidas por Debret e que favorecem o diálogo entre as disciplinas, principalmente entre Arte e História, favorecendo aos alunos aprendizagem mais satisfatórias, contextualizadas e dinâmicas. No entanto, as imagens podem ser trabalhadas em todas as disciplinas, sendo um recurso didático valioso e importante aos alunos.

A sala de aulas e os alunos, portanto serão os receptores das obras de Debret no presente. As experiências do artista serão materializadas de forma unívoca como instrumento de inserção e concretização através do diálogo entre as disciplinas de História e Artes. A discussão de determinados temas, como por exemplo a escravidão, será enriquecida, sobremaneira, com a apresentação das obras de Debret, que, quando se volta para a contemporaneidade, pode contribuir para a superação do racismo em sala de aula. (SANTOS; SILVA, 2014, p. 36).

Verifica-se assim as contribuições das imagens como instrumento de aprendizagem aos alunos e diálogo entre as disciplinas, tornando a aula mais enriquecida, tornando-se também instrumento de reflexão sobre o preconceito e racismo e suas consequências na sociedade.

As obras produzidas por Jean Baptiste Debret exercem um poder de transformação em sala de aula. Os alunos em pleno século XXI terão a oportunidade de "experimentar" a cultura e o cotidiano da sociedade brasileira do século XIX, quase produzindo uma espécie de "viagem no tempo" através das representações e todo o simbolismo que carrega cada obra deste artista que fez uma leitura atenta e interpretou o Brasil, sua 
cultura e a sociedade oitocentista como nenhum outro. (SANTOS; SILVA, 2014, p. 38).

Verifica-se mais uma vez as contribuições de oportunizar aos alunos aulas dinâmicas, produtivas, com significado aos alunos, explorando as imagens e sua situação no tempo e no espaço, oportunizando interpretações, conhecimentos, releitura, análises, dentre outros aspectos relevantes na aprendizagem dos alunos.

- Leitura e releitura de obra de Arte

A leitura e releitura de obra de Arte também são essenciais para desenvolver o senso estético dos alunos, suas habilidades e conhecimento da obra.

Abaixo uma obra bastante conhecida de uma artista famosa, Tarsila do Amaral, que pode trazer reflexões interessantes sobre a cultura e os aspectos estéticos da produção artística brasileira.

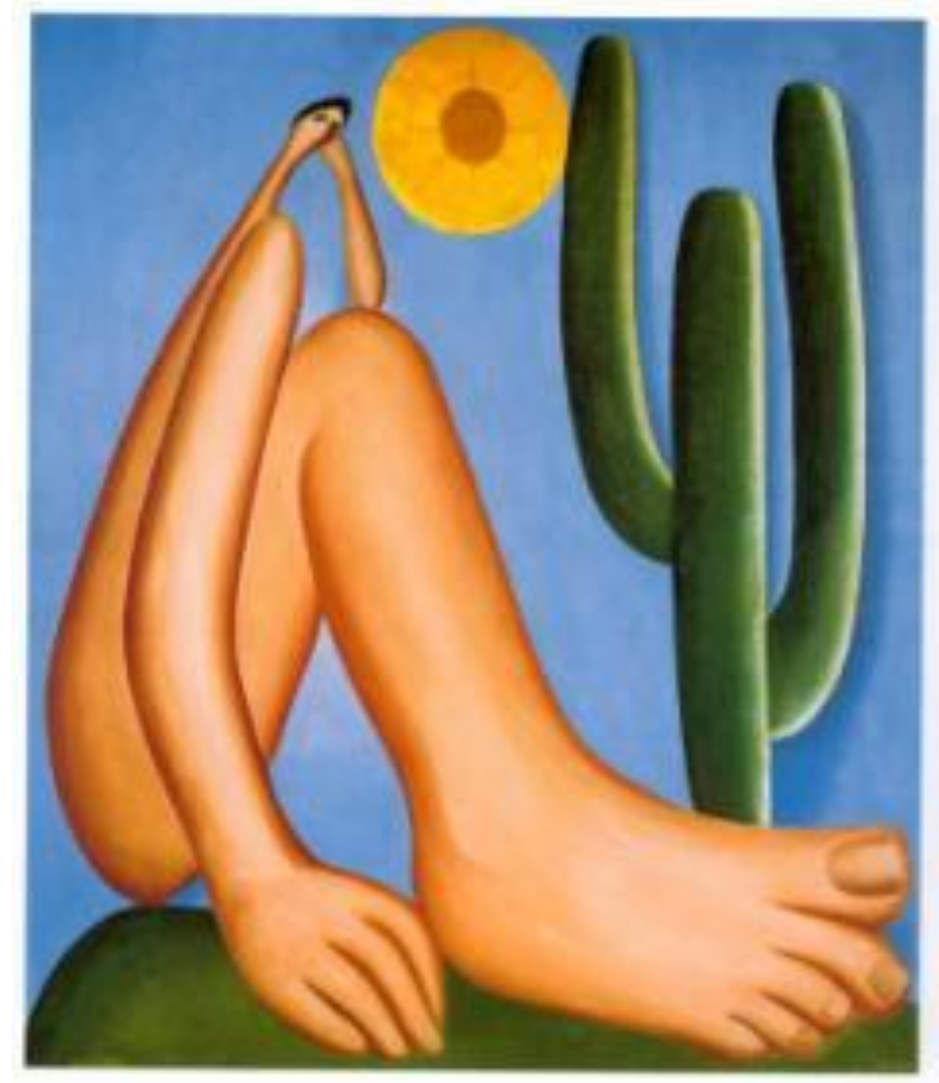

Figura 5: Tarsila do Amaral. Abaporu (1928).

Fonte: https://www.culturagenial.com/abaporu/

A obra "Abaporu" é uma das mais conhecidas de Tarsila do Amaral, sendo de grande importância para análise da mesma através de sua leitura e releitura, 
considerado o contexto em que ela foi criada, os fatos históricos, culturais e sociais aos quais ela está relacionada, para uma maior compreensão aos alunos.

O Abaporu é uma das telas mais conhecidas de Tarsila do Amaral. Para entendermos o significado dessa obra, é necessário um estudo sobre a vida da artista, conhecer o contexto em que a obra foi criada, os fatos históricos, culturais e sociais que estão por trás da imagem, para que possamos entendê-la e interpretá-la.

Sobre o trabalho com esse tipo de imagem, temos a seguinte argumentação:

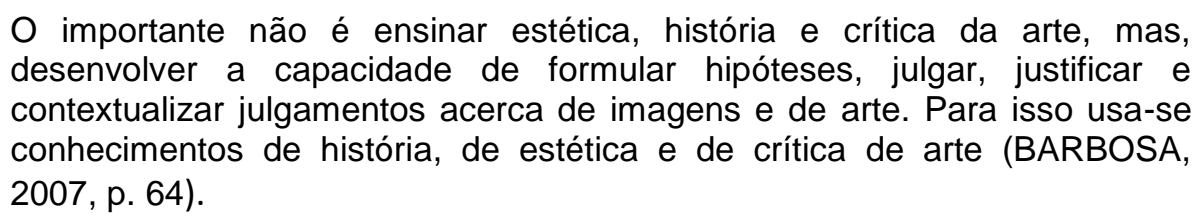

Observa-se que são aspectos relevantes adquiridas aos alunos com a análise de obras de arte, permitindo aos mesmos construírem a sua visão de mundo, despertando o seu senso crítico sobre a realidade e a obra analisada. 


\section{CAPÍTULO II - CAMINHOS PERCORRIDOS}

A estudo foi constituído através de pesquisa bibliográfica, que, segundo Vergara (2005, p. 48), consiste no "estudo sistematizado desenvolvido com base em material publicado em livros, revistas, jornais, redes eletrônicas, isto é, material acessível ao público em geral”.

O estudo foi desenvolvido a partir da abordagem qualitativa, visando analisar os dados construídos a partir de uma pesquisa semiestruturada direcionada a investigação da utilização da imagem na aprendizagem dos alunos na disciplina de Artes visuais no Ensino Fundamental.

Segundo Gerhardt; Silveira (2009), "a pesquisa qualitativa preocupa-se, portanto, com aspectos da realidade que não podem ser quantificados, centrando-se na compreensão e explicação da dinâmica das relações sociais". Dessa forma, observa-se que através dessa metodologia o pesquisador encontrará base para uma melhor compreensão do assunto investigado.

O objetivo geral da pesquisa foi: Discutir o uso da imagem no processo de ensino-aprendizagem na disciplina de Artes no ensino fundamental. O estudo caracterizou-se como uma pesquisa descritiva.

Michel (2009) relata que uma pesquisa descritiva é:

\footnotetext{
Apropriada para a área de ciências humanas e sociais, tem o propósito de analisar, para maior decisão possível, fatos ou fenômenos em sua natureza e característica, procurando observar, registrar e analisar suas relações, conexões e interferências. Procura conhecer e comparar as várias situações que envolvem o comportamento humano, individual ou em grupos sociais ou organizacionais, nos seus aspectos social, econômico cultural etc. (MICHEL 2009, p. 65).
}

Segundo Ribas; Fonseca (2008), a pesquisa descritiva tem por objetivo familiarizar-se com um fenômeno ou descobrir nova percepção acerca do mesmo. Dentro dessa perspectiva, analisa-se os saberes, atitudes, pontos de vista e preferências das pessoas.

Uma das técnicas utilizadas na elaboração deste trabalho foi a aplicação de um questionário com perguntas abertas a professores que trabalham com a disciplina de Artes, visando suas concepções sobre as artes visuais e sua contribuição para a formação dos alunos. 
Um questionário, segundo Manzini (1990/1991, p. 154) e Gil (1999, p.128 apud Char; Diniz; Ribeiro, 2011), pode ser definido "como a técnica de investigação composta por um número mais ou menos elevado de questões apresentadas por escrito às pessoas, tendo por objetivo o conhecimento de opiniões, crenças, sentimentos, interesses, expectativas, situações vivenciadas etc."

Os dados obtidos através da aplicação do questionário foram analisados interpretativamente, com base nos objetivos e na fundamentação teórica, de modo a encontrarmos respostas aos nossos questionamentos.

Para realizarmos o tratamento e análise dos dados coletados, fizemos uso das técnicas da Análise de Conteúdo de Bardin (1977, p. 38), por ser "um conjunto de técnicas de análise das comunicações, que utiliza procedimentos sistemáticos e objetivos de descrição do conteúdo das mensagens".

Nesse sentido, a análise de conteúdo ajuda no processo de "manipulação de mensagens (conteúdo e expressão desse conteúdo), para evidenciar os indicadores que permitem inferir sobre outra realidade que não a da mensagem" (BARDIN, 1977, p. 46).

Através das metodologias utilizadas, foi possível ter uma maior compreensão sobre as contribuições das imagens no ensino das artes visuais no ensino fundamental.

\footnotetext{
O mundo atual caracteriza-se por uma utilização da visualidade em quantidades inigualáveis na história, criando um universo de exposição múltipla para os seres humanos, o que gera a necessidade de uma educação para saber perceber e distinguir sentimentos, sensações, ideias e qualidades. Por isso, o estudo das visualidades pode ser integrado nos projetos educacionais. Tal aprendizagem pode favorecer compreensões mais amplas para que o aluno desenvolva sua sensibilidade, afetividade e seus conceitos e se posicione criticamente. (BRASIL, 1997, p. 45).
}

Nesse sentido, observa-se a necessidade do professor de artes visuais proporcionar aos alunos o contato com a visualidade expressas por diversas maneiras, dentre elas através do estudo de imagens, levando os mesmos a expor sentimentos, sensações, ideias, afetividade, sensibilidade, para que assim possam compreender melhor o mundo à sua volta. 


\section{CAPÍTULO III - ANÁLISE E DISCUSSÃO DOS RESULTADOS}

Este capítulo contém os resultados levantados no decorrer da coleta de dados e análise dos resultados obtidos na pesquisa de campo, ao qual visou discutir e analisar a inserção das imagens na aprendizagem dos alunos em artes visuais no ensino fundamental.

\subsection{PERFIS DOS ENTREVISTADOS}

Foram 3 professores entrevistados, os quais são formados em Artes.

Um dos entrevistados é a Professora 1, sexo feminino, tem 32 anos de idade. É formada Arte Visuais e em Música pela $U A B / U n B$, e também é formada em língua portuguesa pela UFAC, Universidade Federal do Acre. A mesma começou a trabalhar este ano (2017), com aulas de Artes na escola de Ensino Fundamental Padre Damião.

A outra entrevistada é a Professora 2, sexo feminino, tem 31 anos de idade. É formada em Arte Cênicas e em Teatro pela Universidade de Brasília. Atua a cinco anos na profissão.

O outro entrevistado é o Professor 3, sexo masculino, com 43 anos. É formado em Artes Visuais pela Universidade de Brasília, e em Letras pela Universidade Federal do Acre, com especialização em Língua Portuguesa, em gestão pública e em cultura. Possui 25 anos de atuação na profissão.

Os entrevistados foram nomeados P1, P2 e P3 (Professor 1, Professor 2, Professor 3).

Os resultados foram organizados a partir dos seguintes tópicos:

- Interesse pela disciplina de Artes Visuais

- Estratégias utilizadas no processo ensino-aprendizagem em Artes

- O trabalho com a Arte Local

- Os benefícios proporcionados pelo uso da imagem na aprendizagem dos alunos na disciplina de Artes Visuais 


\section{- Interesse pela disciplina de Artes Visuais}

O interesse pela disciplina de Artes por parte do professor é relevante, para que o mesmo tendo afinidade com esta disciplina, possa contribuir de forma mais positiva com a aprendizagem dos alunos.

Ao serem questionados quando se formaram e porque se envolveram com Artes, os entrevistados apresentaram as seguintes respostas:

Me formei em 2015, o meu contato com a arte em si posso dizer começou desde os meus nove anos, onde meus pais me incentivavam, já tocava violão na igreja, e em 2009, me ingressei na faculdade, uma oportunidade que vi tanto para trabalho como pra juntar o que eu gostava de fazer pois sempre gostei da música, foi uma aposta que se abriu na minha vida. (P1).

No ano de 2012. Meu envolvimento com a arte se deu pelo fato de não possuir ensino superior na época e vontade de ser arte educadora. (P2).

Eu me formei em Artes Visuais no ano de 2011, mas na década de 90 eu fiz Letras Vernáculas, pela Universidade Federal do Acre, o meu envolvimento com a arte aconteceu mesmo antes de ser professor, quando era estudante no ensino Fundamental e ensino médio, sempre trabalhei com música, tocava, cantava, na minha adolescência e juventude eu desenhava bastante também, hoje não tenho tanto envolvimento com o desenho, mas com a música eu sempre tive uma afinidade, desde os 5 anos de idade com esse movimento da Arte. (P3).

A partir das falas acima, observa-se que o envolvimento em Arte, de dois dos três participantes, se deu antes de ser professor, devido ao contato com a Arte em sua vida familiar e na escola. Somente uma entrevistada ressaltou que o envolvimento com a Arte se deu pela vontade em ser educadora, e a formação em Arte foi uma oportunidade para realizar esse objetivo.

Nesse sentido, destaca-se o importante papel da escola, em trabalhar a Arte em sua amplitude, de forma concreta, despertando nos alunos a criatividade e o interesse pelo mundo artístico, para que assim esse envolvimento ocorra naturalmente e o aluno tenha condições de desenvolver suas habilidades artísticas com autonomia e competência.

Ao questionar se quando começou a trabalhar com a disciplina de Artes, se já eram formados na área, e se não era, o que mudou na concepção de ensinoaprendizagem das artes, obtemos as seguintes respostas: 
Há apenas 8 meses que estou em sala de aula, na escola Padre Damião, como minha primeira experiência, está sendo um aprendizado novo, pois você não aprende de tudo na graduação, pois na teoria é uma coisa e na prática é outra realidade, ao qual pode ser mais difícil ou mais fácil. Até agora, graças a Deus, eu estou gostando, tenho aprendido muito com meus alunos nas pesquisas. Sobre minha concepção de aprendizagem, não mudou muito do que eu aprendi durante minha graduação, porém dificuldades sempre iremos encontrar dentro do âmbito escolar nem sempre tenho condições de aplicar o que aprendi dentro da faculdade na pratica. (P1).

Sim. Iniciei minha carreira de educador no ano de 2013, já era formada em artes/ teatro. (P2).

Quando eu comecei a trabalhar com artes, no ano de 2000, eu não era formado em artes e com certeza com minha primeira formação foi em artes visuais. Atualmente, também curso música pela Universidade de Brasília, pela UAB, me formando em 2017 que é a minha terceira Graduação, mas com certeza mudou muito depois que eu fiz o curso de Artes Visuais, antes eu era um professor muito teórico, de muito conteúdo, o meu aluno ele não praticava muito a arte, ele não tinha contato prático com a música, com a dança com as artes visuais, era muito mais conteúdo. Enfim, a minha concepção mudou bastante com a Faculdade de Artes Visuais, porque eu comecei a perceber que meu aluno é sim a principal ferramenta desse processo de Ensino Aprendizagem, porque é ele que precisa praticar, ele que precisa ter esse contato direto com a arte, ter essas experiências artísticas, tendo experiências com as diversas manifestações de artes visuais que podem acontecer. Então, hoje, quando eu trabalho com a arte, já chego na sala e praticamente os alunos é que fazem a coisa acontecer, eu apenas oriento e indico, eu dou os toques, eu planejo os projetos, as atividades, mas é o aluno tendo contato diário prático dele com a arte, ele realmente aprendendo artes, fazendo artes. (P3).

Observa-se que nem todos professores de Artes eram formados na área quando começaram a trabalhar com a disciplina de Artes. No entanto, as concepções dos mesmos de ensino-aprendizagem de Artes mudaram após a formação. Os quais destacam como exemplo o foco das artes, que antes era teórico, e que, após a formação, a prática da arte através de suas modalidades puderam ser vivenciadas pelos alunos, os quais passaram a ter contato e aprendizagem mais significativa sobre as Artes em suas diferentes manifestações.

Isso é relevante, pois sabemos que a formação em Artes não traz ao professor uma receita pronta, mas abre novos horizontes, novos olhares e horizontes que os professores podem estar utilizando no processo ensinoaprendizagem dos alunos na disciplina, de modo que favoreça, aos alunos, a criação, a experimentação e a apreciação da artes em suas diferentes modalidades.

Sobre o papel do professor nas aulas de Arte, o Arslan ressalta: 
Os professores tem papel significativo na construção da identidade artística das crianças e dos jovens e devem respeitar os modos de aprendizagem, otimizando o tempo didático com orientações e conteúdos adequados, que dizem respeito tanto aos saberes universais como aqueles que interessam aos alunos por parte de seu cotidiano. É o professor que promove o fazer artístico, a leitura dos objetos estéticos e o refletir sobre a arte a fim de que o aluno se construa como sujeito governado por si mesmo, interagindo com os símbolos de sua cultura. (ARSLAN, 2006, p. 8).

Verifica-se que a atuação do professor na aprendizagem e desenvolvimento dos alunos nas aulas de Arte torna-se essencial, daí a necessidade de realizar um planejamento coerente, que permita aos alunos vivenciar Arte, produzir e interpretar, considerando a proposta Triangular de Arte, proposta por Ana Mae Barbosa, em que prioriza o fazer artístico e a produção.

\section{- Estratégias utilizadas no processo ensino-aprendizagem em Artes}

Ao questionar quais estratégias os professores utilizam no processo ensinoaprendizagem de Artes, os entrevistados apresentaram as seguintes respostas:

Nas minhas aula também tento seguir as estratégias que me foram ensinadas, sempre trabalhando as questões práticas e apreciação sempre juntas, tento valorizar a capacidade única de cada aluno, aqueles que tem mais capacidade e os que não tem, cobro na medida de cada um, tento sempre apreciação de vídeos de imagens por que eu acho que, principalmente pra mim que estou começando neste ano, os alunos aprendem muito através de vídeos e imagens, discussão e debate sobre imagens e vídeos mesmo; filme eu não passo, porque, na área de arte, são poucas horas/aulas por bimestre, então se for passar filmes de longa duração, lá se vão duas aulas perdidas, pode-se dizer assim. Passo muitos vídeos pequenos com relação ao conteúdo e tem muita apreciação sim, fazemos a produção textual e sempre prática, pois o aluno deve fazer a arte praticando, pois a arte em si não está somente na leitura e na escrita mas ele deve apalpar, deve fazer arte, deve tá em contato com o fazer artístico. (P1).

Busco sempre valorizar o que o aluno sabe em relação à arte, seja, dança, teatro ou música. Com base no conhecimento do aluno, organizo minhas atividades. Sendo que trabalho de acordo com os PCNs, ou seja, divido as quatro linguagens das artes cênica pela carga horária anual. São 40 horas aula anual e 4 bimestre anual, sendo que trabalho uma linguagem a cada bimestre. (P2).

Na verdade as estratégias são bastante, afinal de conta a arte que é trabalhada no Ensino Médio, é uma arte que não tem só uma linguagem, mas são as quatro linguagem, nós temos a dança o teatro a música e as artes visuais, então pra cada uma delas há estratégias diferentes, há metodologias diferente com tudo nas quatro linguagens. Eu faço com que meu aluno tenha o contato direto coma arte, por exemplo, na aula de música a gente não fala sobre ela, mas o aluno faz música, ele toca, ele 
canta, ele usa o corpo como percussão corporal, e isso se fundamenta em todas as linguagens incluindo as artes visuais. (P3).

Considerando as falas acima, observa-se que os professores utilizam diversas metodologias e estratégias para o ensino das Artes, isso é positivo, pois sabemos que esta disciplina favorece ao aluno diferentes expressões: apreciar, experimentar, produzir, etc. Desta forma, destaca-se o papel do professor em proporcionar aos alunos nas aulas de artes, a vivência significativa dessa disciplina, envolvendo os eixos propostos pelos Parâmetros Curriculares Nacionais, favorecendo o desenvolvimento e aprendizagem dos alunos.

\section{- O trabalho com a Arte Local}

Ao questionar se a Arte local é trabalhada na escola, de que forma, e em que contexto, os entrevistados apresentaram como respostas:

Por uma questão de conhecimento eu não trabalhei muito infelizmente com meus alunos esse tipo de arte local. Eu não tenho muito experiência, então com minha falta de experiência com um apoio maior, como é meu primeiro ano eu tive muita dificuldade em montar meus planos de aulas o planejamento e tudo mais e eu tive que me virar sozinha, e aí, com eu teria tempo pra arcar com projetos, sempre que as aulas de artes são responsáveis pra arcar com os projetos, tem que organizar os projetos fazer coral, grupos de teatro etc, e era muita coisa. E em Cruzeiro do Sul, a questão da cultura ela não é tão difundida, tem alguns poucos artistas, não é que não tenha, tem alguns sim com certeza, tem a nossa arquitetura, tem artistas que trabalham com artes visuais, tem músicos também, mas por uma questão de tempo e conhecimento eu não me aprofundei nesta área, por que eu gosto de ensinar aquilo que eu tenho domínio, tenho conhecimento do PPP da escola que cobra esse requisito que o aluno deve ter esse conhecimento da arte local, por que a partir do momento que ele tem contato com a arte local é a mesma coisa que está tendo contato com a sua cultura aprendendo também a valorizar. Tenho conhecimento sim que a arte local contribui no ensino de processo de aprendizagem de toda crianças e de todo adolescente e qualquer cidadão, lamento por não ter explorado esse ponto tão importante com meus alunos esse ano, mas pretendo mudar essa concepção didática, se Deus quiser no ano que vem. (P1).

Busco sempre valorizar o que o aluno sabe em relação à arte, seja, dança, teatro ou música. Com base no conhecimento do aluno, organizo minhas atividades. Sendo que trabalho de acordo com os PCNs, ou seja, divido as quatro linguagens das artes cênica pela carga horária anual. São 40 horas aula anual e 4 bimestre anual sendo que, trabalho uma linguagem a cada bimestre. $1^{\circ}$ bimestre, artes visuais, 10 aulas; $2^{\circ}$ bimestre, música, 10 aulas; $3^{\circ}$ bimestre, dança, 10 aulas e; $4^{\circ}$ bimestre, teatro. (P2). 
Sim, além de dar um contexto geral das artes em toda as linguagens, 0 contexto de como é a música no Brasil e no mundo ou como é a arte visual no Brasil e no mundo também trabalho isso dentro da nossa realidade mostrando os artistas o que eles estão fazendo atualmente de artes, até porque nós vivemos dentro de uma floresta amazônica, dentro de uma cidade que tem essa questão do regionalismo muito forte. Então eu trabalho através de projeto dentro da escola, por exemplo, há um projeto ritmo da Amazônia onde trabalhamos a música e a dança dentro da escola Flodoardo Cabral, e lá a gente trabalha todos os ritmos da Amazônia onde os alunos tem contato com a música, com a dança, com os aspectos culturais de cada região da nossa Amazônia, e aí trabalhando a nossa arte local a nossa arte visual por exemplo, a gente trabalha entre tantos artistas, a Marchetaria que é uma das artes visuais, e que temos na cidade um dos maiores nomes do mundo nesta arte que é o artista Maxson. (P3).

Nota-se que a Arte local não é muito trabalhada pelos professores nas aulas de arte, apenas um dos entrevistados ressaltou que trabalha a arte loca através de um projeto realizado na escola Flodoardo Cabral, em que se trabalha a dança e a música de forma mais concreta, e também a artes visuais através do trabalho realizado pela Marchetaria, produzida pelo artista Maxson.

Dessa forma, verifica-se a necessidade de se trabalhar a Arte local tendo em vista sua importância no desenvolvimento e aprendizagem dos alunos, favorecendo aos mesmos uma aprendizagem mais significativa, além de valorizar a arte da região.

É papel da escola incluir as informações sobre a arte produzida nos âmbitos regional, nacional e internacional, compreendendo criticamente também aquelas produzidas pelas mídias para democratizar o conhecimento e ampliar as possibilidades de participação social do aluno. (BRASIL, 1997, p. 35).

Observa-se a relevância de se trabalhar a arte local, nacional e internacional, para que os alunos tenham possibilidades de conhecer as diferenças entre as mesmas e assim torna-se um sujeito ativo e crítico.

Ao indagarmos sobre que tipo de arte local é trabalhada na escola, se são utilizadas imagens, obtive as seguintes falas:

É de extrema importância toda categoria de arte, pois todas tem a sua beleza e seus encantos artísticos real acionados a sentimento, a mesma forma e a pintura ela sendo bem observada você sabendo observar a percepção que aquela arte transmite, ela pode dizer muita coisa. Eu acho que a partir do momento que o aluno entra em contato com a arte, com as artes visuais propriamente dita, é uma forma, um outro lado de ver o mundo com a história tanto em si como da sua localidade e consigo mesmo, por que nós trabalhamos não só a questão mundial, mas também trabalha com seu eu entre si através das cores, ensinando aos alunos que elas também 
podem falar e podem expressar muito a questão de sentimentos, e como eu trabalho, e no primeiro modo que trabalhei foi com leitura de imagens, através das cores trabalhei com eles o auto retrato, onde eles teriam que pintar em estilo cubista, utilizando traços cubistas e diferentes cores conforme a sua personalidade. Fizemos também leituras de quadro de pessoas famosas pesquisas e etc. (P1).

Trabalhamos mais o Artesanato local e desenhos dos próprios alunos. Temos alunos com uma habilidade incrível no desenho, pego esses desenhos e faço exposição para os demais alunos. Sim, a imagem é primordial. (P2).

Se trabalha nas Artes Visuais a Marchetaria, o pintor Delson com pinturas, o próprio artesanato local, se utiliza imagem levamos o artista na escola, fazem entrevistas direta com o aluno, pesquisas na internet, enfim quanto mais próximo a gente poder colocar o nosso alunos com os artistas é melhor, então lá no Flodoardo já foi entre tantos artistas, Maxson que é da Marchetaria, Delson Alves, que é um artista plástico tanto na pintura, tinta a óleo acrílica, ou mesmo no grafite. Entre outros artistas que foram, como Osvaldo Dilson, que sempre quando foram, contam sua história e seu trabalho com a arte, e além de levar as suas obras de artes para os alunos verificarem, olharem e apreciarem. (P3).

Um dos professores pesquisados trabalha com arte local, principalmente através de pinturas e artesanato, já os outros professores não dão muita ênfase à arte local no processo de ensino aprendizagem. Dessa forma, verifica-se a necessidade de se valorizar mais a Arte local nas aulas de artes, de modo que possa ser trabalhada de forma mais contínua, valorizando a criatividade e produções da própria região.

As leituras de objetos artísticos são outra competência que promove a imagem positiva do aprendiz, além de cumprirem o papel de formação cultural, conectam a aprendizagem ao patrimônio cultural. $\mathrm{Na}$ escola $\mathrm{o}$ jovem compreende e se situa no mundo como agente transformador, ao atribuir e extrair significados das produções de críticos, historiadores, jornalistas, artistas e filósofos, com a mediação do professor. (ARSLAN, 2006, p. 9).

Ao perguntar sobre quais artistas locais e suas produções são destacadas no processo de ensino-aprendizagem em Artes e se fazem algum tipo de passeio em museus, exposições, os mesmos responderam:

Trabalhamos a arte local com relação à cultura indígena, na pintura, onde tive o privilégio de dialogar com eles e colocar em pratica a questão da pintura da arte indígena. É uma forma incentivo aos meus alunos, é colocando eles sempre pra praticar, pouca teoria pouca participação e muita apreciação de vídeos e imagens música e a prática, pois é como se o aluno fosse abrir um leque para o mundo e entender o mundo de outra forma, é 
isso que a arte faz, a arte faz que entendemos de forma mais suave, mais eficaz, mais refinada. (P1).

Focamos mais nos cantores e pintores. Nunca levei meus alunos no museu. Levo até os meus alunos as atividades artísticas por meio da música estudo da letra em si, imagens dos desenhos locais para a exposição. Após a exposição das músicas locais e desenhos os alunos fazem a releitura das músicas e dos desenhos. (P2).

Temos o pintor Delson Alves Maxson, com marchetaria, as produções elas fazem parte desse processo de ensino e aprendizagem. E também já levei meus alunos ao museu da cidade quando o mesmo estava funcionado, atualmente não há nenhuma exposição na cidade, e o nosso museu que temos infelizmente se encontra fechado, mas já levei meus alunos ao museu, ao centro cultural do Juruá as seções de cinema no cinema local, pra eles sentirem essa sensação da arte do cinema, e também a própria arquitetura da cidade já serviu de material para o ensino na escola, temos prédios bastantes antigos, prédios centenários, a igreja aqui por si só é uma verdadeira obra de arte, então todo esse aparato da nossa cidade já foi levado pra sala de aula e os alunos, até fazemos essas visitas. (P3).

Verifica-se que alguns professores levam seus alunos para visita em museus e exposições, outros não. Considera que deveria haver uma prática mais voltada para a arte local, trabalhando não somente com os artistas mundiais e brasileiros, mas principalmente os artistas que fazem parte da própria história de vida do aluno, de sua cidade, o que pode servir como incentivo e exemplo para o aluno se tornar um artista.

Diante do questionamento: destaque e descreva os tipos de atividades que foram desenvolvidas com a turma para se trabalhar a arte local, e em que isso contribuiu, os mesmos relataram:

Tiramos fotos, entrevistamos os artesãos locais e confeccionamos na escola alguns objetos que os alunos gostaram mais. Finalizamos com a confecção e exposição de um mural com as fotografias tiradas. (P2).

Uma das atividades foi a reprodução visual, onde os alunos tentavam reproduzir no papel as impressões que os mesmos tiveram nas visitas, que fazemos até esses locais, uma outra atividade foi trabalhando com a fotografia, onde formamos grupos em sala de aula, e cada grupo teve a missão de fotografar prédios históricos arquiteturas novas diferenciadas, novas modernas e contemporânea, foi uma outra atividades que trabalhada também onde todos os alunos criaram blogs, e nesses blogs, então, eles postavam as atividades que eram feitas tanto de reprodução visual como fotografia, ou mesmo de stop motion e apresentações mais áudios visuais. Então a gente tentava fazer várias atividades que podes se trabalhar a nossa arte local. (P3). 
Mediante as respostas acima, compreendemos que os professores utilizam diferentes estratégias para trabalhar a arte local, uns mais criativos que outros. As produções com imagens, fotografias, criação de blogs, apresentações audiovisuais, tudo isso favorece o desenvolvimento do aluno e de sua criatividade.

Dessa forma, destaca-se a necessidade do professor de Artes utilizar diferentes procedimentos de artes em suas diversas modalidades, levando o aluno a experimentar, criar, produzir, apreciar, pois traz contribuições relevantes à sua percepção de mundo e desenvolvimento da criatividade.

- Os benefícios a imagem na aprendizagem dos alunos na disciplina de Artes Visuais

Sobre quais os benefícios que a imagem pode proporcionar na aprendizagem dos alunos na disciplina de Artes Visuais, os entrevistados argumentaram:

As imagens favorecem a aprendizagem dos alunos, desenvolvimento de habilidades e conhecimentos úteis à sua formação. (P1).

A imagem é de suma importância, pois ela completa trás o outro lado do conteúdo em um contexto mais chamativo e atraente para os alunos, infelizmente há uma escarces de profissionais formados em artes visuais na localidade, mas temos bastantes pessoas que tem uma criatividade aguçada para a pintura, onde nós professores de artes levamos até a escola, venho lembrar que não é com frequência que levamos as imagens desses artistas à escola, mas buscamos mostrar em sala de aula os desenhos dos artistas local como incentivo para que eles possam se inspirar, se expressar e mostrar seu talento. (P2).

Acredito que se aprende muito pela visão, é o que nós chamamos de cultura visual, é quando o aluno ver é quando ele pode sentir fisicamente uma obra de arte, ele pode internalizar mais conceitos mais informações, ou seja ele vai aliar o conhecimento teórico daquela obra, daquele artista, das características como visual, acredito que quando você junta a imagem com a formação, o aluno consegue aprender muito mais, e fixar melhor o conhecimento, melhor o conceito. (P3).

Observa-se, através das falas dos professores, que os mesmos atribuem grande importância à Arte na aprendizagem dos alunos, tais como: desenvolvimento das habilidades, favorecimento da criatividade, dinamicidade nas aulas, fortalecimento da cultura visual, informações e conhecimentos importantes aos alunos, favorecimento de uma aprendizagem mais significativa aos alunos. 
Com as entrevistas, também pudemos observar que, nem sempre, trabalhase com imagens de obras de artistas. No entanto, destaca-se a necessidade dos professores de Artes e das demais disciplinas trabalharem de forma mais contínua com as imagens na sala de aula, trazendo contribuições relevantes à aprendizagem dos alunos, além de servir como incentivo ao desenvolvimento artístico dos mesmos.

Assim, a aprendizagem artística traz contribuições relevantes na aprendizagem dos alunos:

\begin{abstract}
A aprendizagem artística deixará no aluno marcas positivas, um sentimento de competência para criar, interpretar objetos artísticos e refletir sobre arte, situar as produções, aprender a lidar com situações novas, e incorporar competências e habilidades para expor publicamente as ideias com autonomia. (ARSLAN, 2006, p .9).
\end{abstract}

São aspectos importantes que será de grande valia ao desenvolvimento dos alunos e de suas habilidades.

\begin{abstract}
Aprender arte é desenvolver progressivamente um percurso de criação pessoal cultivado, ou seja, alimentado pelas interações significativas que o aluno realiza com aqueles que trazem informações pertinentes para o processo de aprendizagem (outros alunos, professores, artistas, especialistas), com fontes de informação (obras, trabalhos dos colegas, acervos, reproduções, mostras, apresentações) e com o seu próprio percurso de criador. (BRASIL, 1997, p. 35).
\end{abstract}

4.2 O ensino de artes, através de imagens, a partir da abordagem triangular do ensino de arte

O Ensino de Artes, através de imagens torna-se essencial na aprendizagem dos alunos e em sua formação cidadã. E a abordagem Triangular no Ensino de Arte, proposto por Ana Mae Barbosa (1998), torna-se relevante, tendo em vista que traz contribuições relevantes ao desenvolvimento artístico dos alunos, que considera três pilares: fazer arte, ler imagens e contextualizá-las no tempo e espaço.

Nesse sentido, verifica-se a relevância da Abordagem Triangular no Ensino de Arte na aprendizagem dos alunos, tendo em vista que possibilita o fazer artístico dos alunos que favorece o desenvolvimento de suas habilidades, a leitura de imagens, compreendendo o seu significado e intenção, além da contextualização do 
tempo e espaço histórico, permitindo aos alunos compreenderem a sua história, adquirindo informações relevantes sobre aspectos culturais diversos.

Visa à formação dos alunos, o desenvolvimento de sua criatividade com autonomia, exprimindo emoções e sentimentos sobre os significados da imagem e da produção artística.

\begin{abstract}
A Abordagem Triangular do Ensino da Arte pontua que a construção do conhecimento em arte acontece quando há o cruzamento entre experimentação, codificação e informação. Considera como sendo seu objeto de conhecimento, a pesquisa e a compreensão das questões que envolvem o modo de inter-relacionamento entre arte e público. "É construtivista, interacionista, dialógica, multiculturalista e pós-moderna, por tudo isso e por articular arte como expressão e como cultura na sala de aula". (RIZZI, 2008, p. 337)
\end{abstract}

Assim, consideramos a relevância da leitura de obras de artes na perspectiva triangular, em que o aluno possa interagir com a obra, construir significados através de sua análise e ao mesmo tempo produzir, considerando as informações adquiridas.

Segundo Rizzi (2008), a forma disciplinarizada de conceber o ensino é fragmentada e prejudica tanto o aspecto qualitativo e quantitativo, impedindo a visão do todo e interfere a intercomunicação entre as várias áreas do conhecimento, ao qual é oposta aos princípios da Abordagem Triangular que permite operar transdisciplinarmente. Tal abordagem tem como desdobramento a interligação entre as diversas áreas do conhecimento, assegurando uma maior aprendizagem aos alunos.

\begin{abstract}
A Abordagem Triangular permite uma interação dinâmica e multidimensional entre as partes e o todo e vice-versa, do contexto do ensino da arte, ou seja, entre as disciplinas básicas da área, entre as outras disciplinas, no inter-relacionamento das três ações básicas: ler, fazer e contextualizar e no inter-relacionamento das quatro ações decorrentes: decodificar, experimentar, refletir e informar. (RIZZI, 2008, p. 345).
\end{abstract}

Essa ações: ler, fazer e contextualizar são essenciais na formação dos estudantes, e como vimos na entrevista, alguns professores utilizam essas práticas, de forma multidisciplinar, o que enriquece muito o aprendizado tanto dos alunos quanto dos próprios professores enquanto educadores. 


\section{CONSIDERAÇÕES FINAIS}

Através deste trabalho de conclusão de Curso, foi possível ter uma reflexão maior sobre a importância que as imagens favorecem no processo ensino e aprendizagem dos alunos em sua formação.

Os objetivos da pesquisa foram alcançados e assim foi possível reconhecer as contribuições que as imagens utilizadas de forma interdisciplinar pode contribuir com a aprendizagem dos alunos na disciplina de Artes Visuais. E ainda destacou-se diferentes metodologias de análise de imagens para uma aprendizagem mais produtiva aos alunos.

Verificou-se a importância do trabalho do professor de Artes e das demais disciplinas, em utilizar as imagens nas aulas das diferentes disciplinas, em especial das Artes Visuais e assim oportunizar experiências significativas aos alunos, proporcionado através do estudo de imagens, incluindo: análise, interpretação, contextualização, apreciação, releitura, produção, pesquisa, dentre outras ações importantes na aprendizagem dos alunos.

Nota-se ainda através das falas dos professores entrevistados, que os mesmos reconhecem a grande contribuição das imagens nas aprendizagem dos alunos, favorecendo o desenvolvimento de habilidades artísticas, aprendizagens, conhecimentos culturais, históricos e sociais.

Enfim, a pesquisa foi concluída com êxito e assim observa-se a necessidade dos professores fortalecerem cada vez mais as aulas de Artes, com dinamicidade, pesquisa, experimentação, produção, análises e interpretações de imagens, oportunizando aos alunos um diálogo com as outras disciplinas e assim favorecendo de fato, uma aprendizagem mais satisfatória aos seus alunos. 


\section{REFERÊNCIAS BIBLIOGRÁFICAS}

BRÁZIA, Paulo Jorge Martins da. Aprendizagem pela Imagem Caso prático nas disciplinas de História e de Geografia. Relatório de Estágio de Mestrado em Ensino da História e da Geografia no $3^{0}$ ciclo do Ensino Básico e no Ensino Secundário, 2014.

CRUZ, Isabela Seabra da. A arte, área do conhecimento no currículo escolar ensino fundamental. 2009. Disponível em: https://www.avm.edu.br/docpdf/monografias_publicadas/posdistancia/41548.pdf. Acesso em: 19/11/2016.

SÃO PAULO (Estado) Secretaria da Educação. Coordenadoria de Estudos e Normas Pedagógicas. $O$ ensino de arte nas séries iniciais: ciclo I / Secretaria da Educação, Coordenadoria de Estudos e Normas Pedagógicas; organização de Roseli Cassar Ventrella e Maria Alice Lima Garcia. - São Paulo FDE, 2006.

SILVA, Rosa Maria da. Artes visuais na escola: uma experiência de ensino e aprendizagem através do olhar e das expressões artísticas dos alunos. Unoesc \& Ciência-ACHS, Joaçaba, v. 2, n. 2, p. 120-128, jul./dez. 2011.

Brasil. Secretaria de Educação Fundamental. Parâmetros curriculares nacionais: arte / Secretaria de Educação Fundamental. - Brasília: MEC / SEF, 1998.

ARSLAN, Luciana Mourão e IAVELBERG, Rosa. O Ensino de Arte no início do século XXI. In:__. Ensino de Arte. São Paulo: Thomson Learning. 2006. p. 1-13

MARTINS, Mirian Celeste Ferreira Dias; Didática do ensino de arte: A língua do Mundo: Poetizar, Fruir e Conhecer Arte / Mirian Celeste Martins, Gisa Picosque, M. Terezinha Telles Guerra. - São Paulo: FTD, 1998.

RIZZI, Maria Christina de Souza Lima. Reflexões sobre a abordagem triangular do ensino da Arte. In: BARBOSA, Ana Mae (Org.). Ensino da Arte: memória e história. São Paulo: Editora Perspectiva, 2008. pp. 335-348. 
SANTOS, Cleyton Rodrigues dos. SILVA, Mariane Cristina da Silva. Escravidão, racismo e sociedade: Debret na sala de aula e o diálogo entre as disciplinas de história e artes. Revista de Crítica Cultural, v. 2, n. 2, 2014

SARDELICH, Maria Emília. Leitura de imagens e cultura visual: desenredando conceitos para a prática educativa. Educar, Curitiba, n. 27, p. 203-219, 2006. Editora UFPR 


\section{APENDICE - A}

\section{PERFIL DO (A) ENTREVISTADO (A)}

Nome:

Sexo:

Idade:

Grau de Instrução:

Formação:

Área de informação:

Tempo na profissão:

1. Quando você se formou, por que se envolveu com a Arte?

2. Quando você começou a trabalhar com a disciplina de Artes, já era formada não área? Se não era formada, o que mudou na concepção de ensino-aprendizagem das artes?

3. Quais estratégias você utiliza no processo de ensino-aprendizagem de Artes?

4. A Arte local é trabalhada na escola? De que forma? Em que contexto?

5. Que tipo de arte local é trabalhada na escola? São utilizadas imagens?

6. Quais artistas locais e suas produções são destacadas no processo de ensinoaprendizagem em Artes? Fazem algum tipo de passeio em museus, exposições. Relate 
7. Destaque e descreva os tipos de atividades que foram desenvolvidas com a turma para se trabalhar a arte local, e em que isso contribuiu?

8. Como a Arte local pode contribuir para o desenvolvimento do ser humano, para o exercício da cidadania?

9. Como os alunos têm reagido ao ter contato com a arte local? Descrever o processo.

10. Quais os benefícios a imagem pode proporcionar na aprendizagem dos alunos na disciplina de Artes Visuais?

11. Como você explora o uso de imagens na disciplina de Artes?

12. Como você incentiva seus alunos a ter interesse pelas aulas de Artes? 